\title{
Okul Müdürlerinin, Okul Temelli Denetim Yaklaşımlarını Belirlemeye Yönelik Bir Ölçek Geliştirme Çalışması
}

DOI: $10.26466 /$ opus.862427

*

\author{
Engin İs * - M. Semih Summak** \\ * Dr. Öğr., Gaziantep Üniversitesi, Eğitim Fak., Gaziantep/Türkiye \\ E-Posta: enginis47@gmail.com \\ ORCID: $\quad$ 0000-0003-4304-0662 \\ ** Doç. Dr., Gaziantep Üniversitesi, Eğitim Fak., Gaziantep/Türkiye \\ E-Posta: summaksemih@gmail.com \\ ORCID: $\underline{0000-0003-4900-6545}$
}

\section{Öz}

$B u$ araştırmanın temel amacı, okul müdürleri tarafından yapılacak öğretmen denetimlerindeki yaklaşımların belirlemeye yönelik güvenilir ve geçerli bir ölçme aracı geliştirmektir. Ölçek geliştirme sürecinde, DeVellis (2017) tarafindan önerilen aşamalar temel alınmıştır. Geliştirilen ölçek ilgili alın yazın taranmasında Glickman vd. (2014) "Denetim ve Öğretimsel Liderlik Gelişimsel Bir Yaklaşım" kitabında tanımladıkları üç farklı okul tipi temel alınarak hazırlanmıştır. Bunun için öncelikle problem tanımlanmış ve geliştirilecek ölçeğin hangi özellikleri ölçeceğine karar verilmiştir. İlgili alanyazın tarandıktan sonra, ölçeğin alt boyutlarına karar verilmiş ve bu alt boyutları ölçecek maddeler yazılmıştır. Ölçek taslağı öncelikle literatüre dayalı olarak oluşturulmuş ve görüşlerini almak amacıyla uzmanların sunulmuştur. Uzmanlardan gelen dönütlere dayalı olarak taslaktan madde çıkarılarak, 43 maddelik taslak ölçek ilkokul ve ortaokullarda çalışan toplam 357 öğretmene uygulanarak elde edilen veriler SPSS programında analiz edilmiştir. Açımlayıı faktör analizi (AFA) sonucu "Otoriter Odaklı Denetim, Sosyal Ağdaşım Temelli Denetim, Gelişim Odaklı Denetim ve İşlemsel Denetim" olmak üzere 4 boyutlu 23 maddelik bir yapı ortaya çıkmıştır. Ölçme aracının geçerliği kapsamında açımlayıcı ve doğrulayıcı faktör analizleri; güvenirlik kapsamında ise Cronbach's Alfa katsayısı, madde toplam korelasyonları yapılmıştır. Açımlayıcı faktör analizinin ardından yapılan doğrulayıcı faktör analizi de kabul edilebilir düzeyde uyum indeksleri vermiştir. Yapılan analizler okul müdürlerinin denetim yaklaşımların belirlemeye yönelik ölçeğin, geçerli ve güvenilir olduğunu ortaya koymuştur.

Anahtar Kelimeler: Okul temelli denetim yaklaşımları ölçeği, Öğretimsel denetim, müdür 


\title{
A Scale Development Study for the Assessment of School Principals' Supervisory Approaches
}

\begin{abstract}
The primary aim of this study is to design a valid and reliable measurement tool to be used in the assessment of supervisory approaches employed by school principals. In the scale development process, the supervision stages suggested by DeVellis (2017) have been taken as basis. The scale to be developed is based on three different school types that are defined by by Glickman et al. (2014) in the book titled "Supervision and Instructional Leadership A Developmental Approach". In course of development process, firstly the problem has been defined and the main features to be measured have been identified. After the relevant literature has been examined, the sub-dimensions of the scale were formed and the items to measure these sub-dimensions were produced. The scale draft has been primarily created on the basis of the literature and has been presented to the experts to get scholarly feedback Based on this feedback, some items have been removed from the draft and the 43-item preliminary scale has been administred to a total of 357 teachers working in primary and secondary schools, and the data obtained have been analyzed by using SPSS. As a result of the exploratory factor analysis (EFA), a 4dimension and 23-item scale structure, namely "Authoritarian-Focused Supervision Social NetworkBased Supervision, Development-Oriented Supervision, and Operational Supervision" as emerged. Exploratory and confirmatory factor analyses within the scope of the validity of the measurement tool; Cronbach's Alpha coefficient and item total correlations have been calculated within the scope of reliability. Confirmatory factorial analysis, executed following the exploratory factor analysis, has also displayed acceptable levels of fit indices. The analysis revealed that the scale, being developed for the assessment of principals' school-based supervisory approaches, has become a valid and reliable tool.
\end{abstract}

Keywords: Supervisory approaches, assessment, School-based, Scale development, School Principal 


\section{Giriş}

Ölçme, bilimin temel etkinliklerinden olup, sosyal araştırma içeriğinde geniş bir alanda hayati bir önem taşımaktadır. Sosyal ve davranışsal bilimlerde doğrudan gözlenemeyen inançlar, beklentiler ve duygular anket ve ölçeklerle araştırma süreçleri tarafından belirlenebilir. Doğrudan araçlarla ölçülmeyen kurumsal değişkenlerin seviyelerini ortaya çıkarmayı amaçlayan ölçme araçlarına ölçekler denir. Dünyaya karşı kuramsal algımızdan dolayı var olduğuna inandığımız fakat doğrudan ölçemediğimiz olguyu ölçmek istediğimizde ölçekler geliştirilir (DeVellis, 2017, ss.1-17). Okul müdürlerinin, okul temelli denetim yaklaşımları doğrudan somut olarak gözlenerek ölçülememektedir. Dolayısıyla okul müdürlerinin, okul temelli denetim yaklaşımlarının belirlenmesi gibi zor bir olguyu ölçmek için bir ölçek geliştirme çalışması yapılması önemlidir. Ayrıca, bu ölçek geliştirme çalışması ile elde edilen sonuçlara dayalı olarak öğretimsel denetim sürecinin daha bilimsel bir tabana oturmasına katkı sağlayacaktır.

\section{Okul Temelli Yönetim ve Okul Müdürlerinin Denetimsel Rolü}

Denetim ve yönetimin tarihsel gelişimlerine bakıldığında her iki kavramın birbiriyle ilişkili olduğu görülmektedir. Yönetim ve denetim fonksiyon olarak birbirinden ayrı düşünülemez. Aksine birbirini tamamlayıcı ve birbirleriyle yüksek ilişki içindedirler (Sergiovanni ve Starratt, 1979, s.10). Glickman, Gordon ve Gordon, (2002, s.9) denetimin öğretim liderliği ile aynı olduğunu vurgulamışlardır. Dolayısıyla denetimin bir liderlik becerisi olduğu söylenebilir. Çünkü liderlik örgüte ve bireylere rehberlik etmek ve onları uygun şekilde yönlendirmektir (Harris, 1985, s.739). Denetmenin en önemli sorumluluğu, eğitim paydaşlarına liderlik etmektir. Bu tür bir liderlikte öğretmene rehberlik ederek, mesleki gelişimini artırmak için son derece önemlidir (Mohanty, 2005: s.297).

Denetim için araştırmacıların uzlaştığı ve ortak kabul gören bir tanım yapmak oldukça güçtür. Araştırmacılar denetim kavramını farklı bakış açılarından yorumlamışlardır. Zepeda (2016) öğretimsel denetimi, öğretim sürecinde öğretim programları ve okullarda yapılan öğretimin 
geliştirilmesini amaçlayan bütün uygulamalar ve değerlendirmeler olarak ifade etmiştir. Segiovanni ve Starratt (2006) ise denetimin, öğretimi geliştirmesi amacının yanında, okullarda hedeflenen ve saptanan amaçların gerçekleşmesi, okuldaki iklim ve insanların birbirleriyle olumlu ilişkilerine bağlı olduğunu vurgulamışlardır. Sullivan ve Glanz (2015) ise öğretimsel denetimi, “öğretimin iyileştirilmesi ve öğrencilerin eğitimsel başarılarını artırmak için öğretmenin, öğretim süreçlerine odaklanma" şeklinde ifade etmişlerdir.

Thrupp (1998), okul temelli denetimin, "arkadaşça denetim" temelinde, demokratik bir değerlendirme olduğunu ifade etmiştir. Bülbül, Özdem, Tunç ve İnandı,( 2013, s.2109) okul temelli denetimi, okulların, üstün ve zayıf yönlerini belirleyebilecekleri, eğitim bileşenlerinin, kendi eylemlerinden sorumlu oldukları bir "özdenetim" mekanizması olduğu şeklinde açıklamışlardır. Hofman, Dijkstra ve Hofman (2009), okul temelli denetimin geniş düzlemde, amaç belirleme, planlama, değerlendirme ve yeni gelişme standartları oluşturmaya yönelik sistematik bir süreç olduğunu söylemişlerdir. Davies ve Rudd (2001), okul temelli denetimi, okul ve öğretmenler için durum değerlendirme yapmalarını sağlayan bir 'ayna' olduğu şeklinde belirtmişlerdir. $\mathrm{Bu}$ yaklaşımın okullarda denetimde katılımcı demokrasiyi genişletmede, meslektaş etkileşimli ve öğretimi geliştiren denetim anlayışının gelişmesinde önemli katkı sağladığı ifade edilebilir (Sullivan ve Glanz, 2015, s.37).

Okul temelli denetim uygulamaları dünyada ülkeler bazında farklılıklar gösterebilmektedir. Avrupa'da, yönetimde yerelleşme paradigmasını benimsemenin sonucu olarak ülkelerin birçoğunda okulların kendi öğretimsel öz değerlendirmelerini yapmaları olarak görülürken; Amerika, Güney Kore ve Japonya gibi ülkelerde okulun bağımsızlığı, hesap verebilirlik yaklaşımı içinde görülmüştür. $\mathrm{Bu}$ yaklaşımda yönetim ve denetim görevinin okul müdürlerine bırakıldığı gibi, bazen de müdür ve okul kurullarının birlikte yönetimi şeklinde uygulanmaktadır (David 1996). Ülkemizde ise 2015 yılı itibariyle diş denetim kaldırılarak, okullarda öğretimsel denetim akademik anlamda sadece okul müdürleri tarafından uygulanmaktadır. Türkiye'de okul temelli denetim olarak kavramsallaştırılan bir uygulama bulunmamakla (Bülbül vd.,2013, s. 2106) birlikte, maarif müfettişlerin öğretmenleri 
değerlendirme uygulamasının kaldırılması, öğretmenlerin okul müdürleri tarafından değerlendirilmesi ile müdürlerin denetimsel yetki alanlarının genişletilmesi okul temelli denetim bağlamında ele alınabilir. Literatürde yapılan birçok araştırmada öğretmenler, okullarda öğretimsel denetimin müdürler tarafından yapılmasını istediklerini ifade ederek desteklemişlerdir (Arslanargun ve Göksoy, 2013; Altun, 2014; Yeşil ve Kış, 2015; Can ve Gündüz, 2016; Fırıncıŏlu, 2014; Gündüz, 2016; Summak ve İş, 2018; Yıldız vd., 2016; Deniz ve Saylık, 2018; Tonbul ve Baysülen, 2017). Ülkemizde yapılan bu değişim ile birlikte, okullardaki ders denetimi uygulamalarının, öğretim süreçlerine katkısının öğretmenler tarafından nasıl algılandığının, okul müdürlerinin "denetim" görevlerini yaparken kullandıkları yöntemler ve denetimsel yaklaşımlarının belirlenmesine yönelik bir ölçme aracının geliştirilmesi önem kazanmıştır.

Okul müdürlerinin denetimsel rollerinde meydana gelen değişim ve gelişmeler politik ekonomik, sosyal, kültürel ve teknolojik gelişmelere paralel bir yol izlemiştir. Okul yöneticiliğine 1900'lü yılların başlangıcında bilimsel işletmecilik yaklaşımında olduğu gibi pozisyon temeline ve doğal olarak hiyerarşiye dayalı yöneticilik modeli ön plana çıkarken; 1950'lerden sonra okul müdürlerin rolleri geleneksel yönetim rolü yanı sıra öğretim liderliği ve dönüşümcü liderliği de içene alan geniş bir yelpaze içerisinde tanımlanmaya başlanmıştır. Bu yeni eğilim ile birlikte eğitim programı ve öğretimin yönetimi konusu, okul müdürünün rol tanımlarının merkezine yerleşmiştir (Gümüşeli, 2014; Heck vd., 1990; Glickman, 1985). Bu süreçte müdürün rolü öğretmen müdürden okul müdürüne doğru değişmiştir. Bu kapsamda müdürlerden öğretmen ve öğrencileri denetleme, destekleme ve öğretimle ilgili konularda daha doğrudan bir rol üstlenmeleri istenmiştir (Edmonds, 1979; Sweney, 1992).

Okul müdürlerinin denetçi rolleri konusunda, Luehe (1989, s. 26), okul müdürlerinin en önemli denetsel görevlerinin öğretimin denetimi olduğunu ifade etmiştir. Oliva ve Pawlas (2004, s.14), okul müdürlerinin okullarında uygulanan eğitim programı ve öğretim için sorumlu olduklarını, öğretimsel denetimin okul müdürlerinin birçok görevlerinden biri olduğunu öne sürmüşlerdir. Zepeda (2007, s. 181), okuldaki öğretimsel programlar için nihai sorumluluğun okul 
müdüründe olduğunu ileri sürmüş, sınıfın okulun kalbi olduğuna dikkat çekerek okul müdürünün zaman ve enerjisini buraya odaklaması gerektiğini belirtmiştir. Glanz (2006, s. 55), okul müdürlerinin kendilerini "öğretmenlerin öğretmenleri" olarak görmeleri gerektiğini ileri sürmüştür. İyi okulların işaretlerinden birinin öğretimsel liderliğe öncelik vermek olduğunu belirten Glanz, okulların her zaman öğretimsel lider olan okul müdürleri aramaları gerektiğini ifade etmiştir.

Araştırmacı ve uygulamacılar, okul etkililiğinde öğretim liderliğinin önemli rolünün olduğu konusunda görüş birliği içerisindedirler. 1980'li yıllarda yapılan birçok çalışmada okul müdürünün öğretim liderliği rolünün iki temel boyutundan birisinin öğretmenleri izlemek diğerinin de onların sürekli gelişimini sağlamak olduğu vurgulanmıştır (Gümüşeli, 2014). İçinde bulunduğumuz dönemde özellikle öğretmenlerin ders denetimi uygulamaları etkili, verimli öğretme ve öğrenme basamaklarının ayrılmaz bir unsuru olmuştur (Sullivan ve Glanz, 2015). Okulların belirlenen amaçları gerçekleştirmeleri için öğretmenlerin desteklenip iş başında yetiştirilmesi büyük önem arz etmektedir. Okullarda öğretmenlerin mesleki gelişimlerini teşvik eden, onları destekleyen ve onların yollarını açan kişilerin başında okul müdürleri gelmektedir. Okul müdürleri, okul gelişimi için gerçekleştirilecek eğitim ve öğretim faaliyetlerinin tümünden sorumludurlar. Dolayısıyla okul müdürlerinin en önemli görevlerinin başında öğretmene yapılacak mesleki rehberlik gelmektedir (Dufor ve Berkey,1995). Catano ve Stronge (2007) çalışmalarında, okul müdürleri tarafından yapılan öğretmen denetimlerinin okulun amaçlarına ulaşmasını sağladığını ve öğretmenlerin mesleki açıdan gelişimine katkı yaptı̆̆ını ifade etmişlerdir. Terry'e (1995) göre müdürlerin öğretmenleri mesleki olarak desteklemeleri okullar için bir zorunluluktur. Çünkü etkili okullar incelendiğinde müdürlerin öğretmenlere rehberlik ederek desteklediği onların performanslarını arttırmak için çalıştıkları, öğretmenlerin mesleki gelişimlerini odaklandıkları görülmektedir. Okullarda müdürler tarafından öğretmenlere yapılan mesleki rehberlik, bilgi, beceri aktarımları ile desteklemeleri, öğretmenlerin kendilerini okulda güçlü hissetmelerini ve profesyonelleşmesine katkı sağlar. Melenyzer, (1990) öğrencilerin ve eğitim sisteminin gelişmesi, eğitimsel çıtıların artması, eğitimde profesyonelleşme, çözüm odaklı bir eğitim, 
okulları geliştirme hızlandırması isteniyorsa okul müdürlerinin öğretmenleri mesleki olarak güçlendirmeleri hem bir gereklilik hem de zaruri bir ihtiyaç olduğunu belirtmiştir. Bu bağlamda okul müdürünün asli görevi, öğretmenlerin mesleki becerilerinin geliştirilmesini sağlamak ve böylelikle de öğrencinin gelişim, öğrenme ve başarısına katkı sunmaktır.

Okul müdürleri tarafından gerçekleştirilen öğretmen denetimlerinin öğretim etkinliklerinin yerine getirilmesi bakımından da oldukça önem arz eder. Öğretmenleri meslek içinde yetiştirmek, öğretimsel denetim ile yapılacak etkin mesleki rehberlikle sağlanabilir. Okullarda yapılacak ders denetim uygulamaları, denetim alanında belirli düzeyde eğitim almış donanımlı ve alanında deneyimli okul müdürleri ile gerçekleştirilebilir (Grizzard, 2007). Öğretmen denetiminin okul müdürlerinin görev alanına eklemlenmesi, müdürlerin öğretimsel liderlik rollerini de kompleks hâle getirmiştir (Memduhoğlu ve Zengin, 2012). Bu nedenle okul müdürlerinin okul temelli denetim yaklaşımlarını betimleyen bir veri toplama aracının geliştirilmesi önem arz etmektedir. Yapılan alanyazın taraması çerçevesinde Türkiye'de müdürlerin, okul temelli denetim yaklaşımlarını betimleyen bir veri toplama aracına rastlanamamıştır. Dolayısıyla, okul müdürlerinin denetim yaklaşımlarını belirlemede kullanılabilecek çok boyutlu bir ölçeğin geliştirilmesinin gerektiği gerçekliğini yansıtmaktadır. Araştırmada geliştirilen okul temelli denetim yaklaşımlarını betimleyen, güvenilir ve geçerli bir veri toplama aracının geliştirilmesinin ulusal alanyazında belli bir boşluğu doldurmaya katkı sağlayacağına inanılmaktadır.

\section{Araştırmanın Amacı ve Önemi}

Araştırmanın amacl, okul müdürlerinin okul temelli denetim yaklaşımlarını betimleyecek güvenilir ve geçerli bir veri toplama aracı geliştirmektir. Türkiye'de okul müdürlerinin, okul temelli denetim yaklaşımlarını betimleyen bir veri toplama aracına rastlanamamıştır. $\mathrm{Bu}$ ölçek geliştirme çalışmasında; Türk eğitim sisteminde, okul müdürlerinin uyguladıkları okul temelli denetim yaklaşımlarını betimleyen, geçerli ve güvenilir bir veri toplama aracı geliştirerek uygulayıcı ve alanyazına katkı sağlaması umulmaktadır. Araştırmanın; 
okul müdürleri tarafından gerçekleştirilen denetim yaklaşımları uygulamalarının geliştirilmesinin önemine ilişkin alanyazında bir farkındalık oluşturulması de beklenmektedir.

\section{Yöntem}

\section{Araştırmanın Modeli}

Araştırma tarama modelinde betimsel bir çalışmadır. Tarama modeli, bir grubu inceleyerek o grubun görüşlerini, tutumlarını, eğilimlerini nicel veya sayısal olarak betimleyerek, elde edilen sonuçlara göre araştırmacı grup hakkında genellemede bulunulur (Creswell, 2009).

\section{Evren ve Örneklem}

Çalışmanın örneklemi, 2017-2018 eğitim-öğretim yılında Mardin ilinde çalışan ilkokullarda 191 ve ortaokullarda 166 öğretmen olmak üzere toplam 357 öğretmenden oluşmaktadır. Örneklem, basit tesadüfi örnekleme yöntemle seçilmiştir (Gliner vd., 2015).

\section{Ölçme Aracına İlişkin Geliştirme Süreçleri}

Araştırmada ölçek geliştirme sürecinde, DeVellis (2017) tarafından önerilen aşamalar temel alınmıştır. Bunun için öncelikle problem tanımlanmış ve geliştirilecek ölçeğin hangi özellikleri ölçeceğine karar verilmiştir. İlgili alanyazın tarandıktan sonra, ölçeğin alt boyutlarına karar verilmiş ve bu alt boyutları ölçecek maddelerin yazılmasına başlanmıştır.

Çalışmada takip edilen ölçek geliştirme aşamaları (DeVellis, 2017, s.73)

1. Aşama: Ölçmek istenen Yapının belirlenmesi, Problem Tanımlama.

2. Aşama: Literatür Tarama.

3. Aşama: Soru Yazma, Madde Havuzu Oluşturma.

4. Aşama: Ölçme Biçimin Belirlenmesi. 
5. Aşama: Başlangıç Madde Havuzunun Uzmanlar Tarafından Gözden Geçirilmesi.

6. Aşama: Maddelerin Pilot uygulamasının Yapılması.

7. Aşama: Maddelerin Faktör Analizlerin Yapılması.

8. Aşama: Ölçeğin Son Şeklinin Verilmesi.

Geliştirilecek ölçek ilgili alın yazın taranması ile Glickman vd. (2014) “Denetim ve Öğretimsel Liderlik Gelişimsel Bir Yaklaşım” kitabında tanımladıkları üç farklı okul tipi olan;

1. Hiyerarşi ve mesleki yalnızlığın özelliklerinin bulunduğu geleneksel okul,

2. Mesleki yalnızlaşma ve arkadaşça etkileşim özellikleri ile sosyal etkileşimli okul,

3. Öğrenme ve öğretmeyi geliştirme odaklı meslektaş odaklı okul tipleri temel alınarak madde havuzu oluşturulmuştur.

Süreç olarak; oluşturulan madde havuzu gözden geçirilecek içerik alanında bilgili ve uzman kişilere ulaşılarak uzman yorumlarına göre kapsam ve görünüm geçerliliği yapılmıştır. Uzman kişilerden ölçmek istenen yapı için her bir maddenin uygunluğu, maddelerin anlaşılırlığ ve özgünlügüne dair değerlendirmeler yapmak için gerekli yönergeler oluşturuldu (DeVellis, 2017: s.100). Madde havuzu alanında uzman olan eğitim bilimlerinde görevli 3 profesör, 3 doçent, 4 doktor öğretim üyesine uzman yorumu için yönergelerin gönderimi yapıldı. 8 kişiden uzman görüşü olarak geri dönüt sağlandı. Bir profesör ve 1 doktor öğretim üyesinden geri dönüt sağlanamadı. Uzman kişilerden, her madde ile ilgili görüşlerini 1) uygun, 2) uygun değil ve 3) düzeltmeli şeklinde görüş ve önerilerini belirtmeleri istenmiş̧ir. Ardından taslağın, oluşan son hâli bir ölçme değerlendirme uzmanına ve son olarak ölçeğin anlaşılırlığı, dil ve imlâ kuralları için Türk Dili ve Edebiyatı alanında uzman bir kişiye gönderilmiştir. Oluşturulan ölçeğin tüm uzman görüşlerinin değerlendirilmesi ve pilot uygulaması sonrası oluşan ölçek taslak madde sayıları aşağıda tablo 1'de verilmiştir. 
Tablo 1. Uzman görüşünden önce ve sonraki madde havuzu

\begin{tabular}{cllll}
\hline & & & Önce & Son Hali \\
\hline & 1. & Meslektaş Odaklı Okul & 64 & 15 \\
& 2. & Geleneksel Okul & 62 & 16 \\
& 3. & Sosyal etkileşimli okul & 43 & 12 \\
Toplam: & & 169 & 43 \\
\hline
\end{tabular}

Alan uzmanlarının görüşlerinin alımasından sonra oluşan ölçekteki maddeler göz önüne alınarak ölçeğin likert tipi, ölçek maddelerinin $5^{\prime}$ li likert şeklinde oluşturuldu. Ölçek; katılımcıların ifadelere ilişkin algılarını belirtmeleri için "1- Kesinlikle Katılmıyorum, 2- Katılmıyorum, 3- Kismen Katıliyorum, 4- Katıliyorum, 5- Kesinlikle Katıliyorum” şeklinde düzenlenmiştir.

\section{Bulgular}

Bu bölüm altında sırasıyla "Okul temelli denetim yaklaşımları ölçeği"ni geliştirme sürecinde yapılan açımlayıcı ve doğrulayıcı faktör analizleri, iç tutarlılık ve güvenirliğe ilişkin bulgular verilmiştir.

\section{Açımlayıcı Faktör Analizi}

Ölçeğin yap1 geçerliğini belirlemek amacıyla geçerlik, güvenirlik çalışmaları için madde analizleri yapıldı. Ölçek geliştirme örneklemine uygulaması ile açımlayıcı ve doğrulayıcı faktör analizleri olmak üzere iki aşamada gerçekleştirildi. Faktör analizi, bir faktörleştirme ya da faktör adı verilen yeni kavramları ortaya çıkarma ya da maddelerin faktör yük değerlerini kullanarak kavramların işlevsel tanımlarını elde etme süreci olarak da tanımlanır. Açımlayıcı faktör analizinde, değişkenler arasındaki ilişkilerden hareketle faktör bulmaya yönelik bir işlem; doğrulayıcı faktör analizinde ise değişkenler arasındaki ilişkiye dair daha önce saptanan bir hipotezin ya da kuramın test edilmesi söz konusudur (Büyüköztürk, 2020). Döndürme işleminde ise Varimax yöntemi kullanılmıştır.

Faktör analizinde aynı yapıyı ölçmeyen maddelerin ayıklanmasında Büyüköztürk (2020, s.134-135)'ün ve Gliner vd., (2015, s.222)'nin ortaya koyduğu aşağıdaki ölçüler dikkate alınmıştır. 
- "Maddelerin yer aldikları faktörlerdeki yük değerlerinin yüksek olması. Faktör yük değerlerinin, 0.45 ya da daha yüksek olması seçim için iyi bir ölçü olmakla beraber uygulamada az sayıda madde için bu sınır değeri, 0.30'a kadar indirilebilir.

- Maddelerin tek bir faktörde yüksek yük değerine, diğer faktörlerde ise düşük yük değerine sahip olması

- Önemli faktörlerin herhangi bir maddede birlikte açıkladıkları ortak faktör varyansinın yüksek olmasi.

- Öz değerin faktör analizinde, 1 ya da 1'den daha büyük olan faktörler önemli faktörler olarak alınır.

- Bu süreçte, verilerin faktör analizi için uygunluğu KaiserMeyer-Olkin (KMO) ve Bartlett Sphericity testi sonuçlarn incelenmelidir. Faktörler elde etmek için dik döndürme tekniklerinden "varimax" döndürme tekniğgi kullanılmıştır. Kaiser-Meyer-Olkin (KMO)'nun. 60'dan yüksek çıkması ve Bartlett Sphericity testi sonuçlarmdaki-kare istatistiğinin anlamlı çıkması, veri matrisinin uygun olduğunun göstergeleridir."

Bununla birlikte verilerin gözlem sayısı için, DFA için 100-200 arasında (Kline, 2005) ve her maddeye 5-10 katılımcinın olmasina (Grimm \& Yarnold, 1995) dikkat edilmiştir.

Açımlayıcı Faktör Analizi için veri yapısının uygunluğu ve örneklemin temel bileşenler analizine uygunluğunu belirlemek için Kaiser-Meyer-Olkin (KMO) ve Bartlett Sphericity testi sonuçları incelenmiştir (Tabachnick ve Fidell, 2007; Worthington \& Whittaker, 2006). Tavşancil (2019, s.50) "KMO sayısının 1'e yakın mükemmel, .80 'lerde olmasını çok iyi ve .70 ile .60 'larda olmasını ise vasat olarak ifade ederken"; Kalaycı (2010) ise .50'nin üzerinde olmasını yeterli görmüştür. Çalışmada Kaiser-Meyer-Olkin (KMO) .924 olarak çıkması örneklem büyüklüğü yeterli olduğu görülmüştür. 
Tablo 2. Kaiser-Meyer-Olkin (KMO) ve Bartlett Sphericity testi sonuçları

Kaiser-Meyer-Olkin Measure of Sampling Adequacy

Bartlett's Test of Sphericity Approx. Chi-Square

Df

Sig.
.924

4746,641

253

.000

Açımlayıcı Faktör Analizi ile maddelerin yük değerleri incelenmiştir. Maddelerin yük değerlerinin 0.30 ile 0.59 arası orta düzey, 0.60 ve üstü madde yük değerleri ise yüksek düzey olarak ifade edilmektedir (Büyüköztürk,2020, s.134).

Tablo 3. Ölçek maddelerine ilişkin faktör yük değerleri (Rotated Component Matrix ${ }^{a}$

\begin{tabular}{|c|c|c|c|c|}
\hline \multirow[t]{2}{*}{ MADDELER } & \multicolumn{4}{|c|}{ FAKTÖRLER } \\
\hline & 1 & 2 & 3 & 4 \\
\hline D14 & 832 & & & \\
\hline D13 & 828 & & & \\
\hline D15 & 786, & & & \\
\hline D10 & 780 & & & \\
\hline D7 & ,755 & & & \\
\hline D9 & 746 & & & \\
\hline D12 & 723 & & & \\
\hline D6 & 672 & & & \\
\hline D8 & 655 & & & \\
\hline B31 & & ,746 & & \\
\hline B18 & & 734 & & \\
\hline B25 & & ,732 & & \\
\hline B29 & & ,731 & & \\
\hline B27 & & 693 & & \\
\hline B21 & & 650 & & \\
\hline S36 & & & ,803 & \\
\hline B24 & & & 787 & \\
\hline B26 & & & ,718 & \\
\hline S37 & & & ,712 & \\
\hline B19 & & &, 554 & \\
\hline S43 & & & & 722 \\
\hline S39 & & & & 704 \\
\hline S38 & & & & 616 \\
\hline
\end{tabular}

"Component Matrix" tablosu incelediğinde 23 maddenin faktör yük değerlerinin 0.554 ve üzeri olduğu görülmektedir. Bu bulgular, ölçeğin genel bir faktöre sahip olduğunu göstermektedir. Ölçek, 3 boyut üzerine tasarlanmasına rağmen Açımlayıcı Faktör Analizi sonuçları, ölçeği 4 
faktör altında toplamıştır. Ayrıca, ölçeğn faktör sayısına karar verme sürecinde, çizgi grafigi kullanılmıştır. Faktör döndürme sonuçları (Rotated Component Matrix) incelediğinde; D6, D8, D9, D10, D12, D13, D14, D15 maddeleri birinci faktör; B18, B21, B25, B27, B29, B31 maddeleri ikinci faktör; B19, B24, B26, S36 ve S37 maddeleri üçüncü faktör; S38, S39 ve S43 maddelerinin ise dördüncü faktöre daha yüksek değerler verdikleri anlaşılmaktadır. Bu sonuçlara göre; ölçeğin birinci faktörü 9 maddeden, ikinci faktörü 6 maddeden, üçüncü faktörü 5 maddeden, dördüncü faktörü 3 madde olmak üzere toplam 23 maddeden oluştuğu belirlenmiştir. Faktör analizlerinde, öz değeri 1 ve/veya 1'den büyük olan faktörler önemli görüldüğünden (Gliner vd., 2015, s. 221; Büyüköztürk, 2020, s.135; Can, 2018), 23 maddenin, öz değerinin birden büyük olan dört faktör altında toplandığı görülmektedir. 20 maddenin açımlayıcı faktör analizi sonucunda yük değerlerinin düşük olmasından dolayı atılmıştır. Bu sonuçlara göre, ölçeğin 23 maddeden oluşan dört faktörlü bir yapı gösterdiği söylenebilir.

Tablo 4. Ölçeğin 4 faktöre yönelik özdeğer ve varyans değerleri

\begin{tabular}{llll}
\hline Faktör & Özdeğer & Varyans yüzdesi & Toplam varyans \\
\hline 1 & 5.902 & 25.660 & 25.660 \\
2 & 3.918 & 17.033 & 42.692 \\
3 & 2.967 & 12.902 & 55.594 \\
4 & 1.954 & 8.494 & 64.089 \\
Toplam: & & & $\mathbf{6 4 . 0 8 9}$ \\
\hline
\end{tabular}

Tabloda açıklanan toplam varyans ve döndürülmüş bileşenler matrisi incelediğinde, 4 faktörün toplam varyansı \% 64.089'nu açıkladığ görülmektedir. Dört faktörde; birinci faktörün 25.660 oranında, ikinci faktörün 17.033 oranında, üçüncü faktörün 12.902 oranında ve dördüncü faktörün 8.494 oranında toplam varyansa katkı sağlamıştır. Ayrıca, sosyal bilimlerde varyans oranları $\% 40$ ile $\% 60$ arasında yeterli kabul edildiğinden (Şencan, 2005; Tavşancıl, 2019) ulaşılan \%64.089 değerinin iyi bir oran olduğu söylenebilir (Büyüköztürk, 2020). Aynı zamanda bu sonuçlar ölçeğin yapı geçerliliği için kabul edilebilir düzeyde olduğunu da göstermektedir.

Ölçeğin güvenirlik ve geçerlik analizleri için önce taslak ölçeğin kapsam geçerliğine bakılmış, sonra yapı geçerliliği için faktör analizi 
yapılmıştır. Bu işlemlerin ardından ölçeğin tümü, alt faktörler ve her bir alt faktörde yer alan ölçek maddelerinin ayrı ayrı güvenirlik analizleri yapılmıştır. Ölçeğin güvenirliği için bu araştırmada ölçeğin ölçmek istenilen yapıyı ne derece ölçtügüüü belirlemek için ölçeğin tamamı için, ayrıca boyutlar bazında da ayrı ayrı Ölçeğin güvenirliğinin hesaplanmasında Cronbach Alpha yöntemi kullanılmıştır. Güvenirlik, ölçme aracının tutarlı ve yordanabilir biçimlerde uygulanmasıdır. Güvenirlik, bir değişkenin bir madde setini neyin etkilediğini belirlemek için kullanılır. Ölçekler, ortak bir örtük değişkeni paylaşan güvenilir maddelerden oluştuğu sürece güvenilirdir. Ölçeklerde madde iç tutarlılık genel olarak Cronbach alfa katsayısı ile özdeşleştirilir. Alfa katsayısı, örtük değişkenin gerçek puanına atfedilecek olan ölçekteki varyans oranıdır (DeVellis, 2017: s.57). "Bir ölçekte güvenirlik için katsayısının .70 ve daha yüksek olması yeterli görülmektedir" (Büyüköztürk, 2020: s. 183). Ölçek güvenirlik kat sayıları tablo 5'de gösterilmiştir.

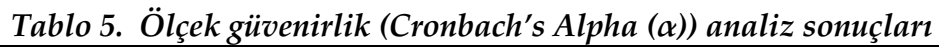

\begin{tabular}{lll}
\hline Faktör & Madde sayisi & Cronbach's Alpha $(\alpha)$ \\
\hline 1 & 9 & .942 \\
2 & 6 & .853 \\
3 & 5 & .807 \\
4 & 3 & .632 \\
Toplam: & 23 & .844 \\
\hline
\end{tabular}

Ölçeğin bütün boyutların toplamında Cronbach's Alpha $(\alpha)$ değerinin .844 olması, ölçeğin yüksek güvenilir olduğunu göstermektedir. Ölçeğin faktörler bazında Cronbach's Alpha $(\alpha)$ değerlerinin .63 ile .94 arasında olduğu görülmektedir. Bu sonuç gözönene alındığında, ölçekteki maddeler için verilen cevapların tutarlı ve kullanılabilir olduğu söylenebilir. Dolayısıyla ölçeğin tümü ve faktörlerin aldığı Cronbach's Alpha $(\alpha)$ değerleri ölçeğin araştırma grubu için güvenilir olduğu sonucuna varılmıştır. 


\section{Doğrulayıcı Faktör Analizi}

Ölçeğin ikinci aşamasında, değişkenler arasındaki ilişkilerin test edilmesi ve doğrulanması için doğrulayıcı faktör analizi (DFA) yapılmıştır (Çokluk vd., 2018). Doğrulayıcı faktör analizi ile ölçeğin geçerliğini tespit etmek için uygulanan açımlayıcı faktör analizi ile belirlenen dört faktörlü yapının doğruluğunun test edilmesi amaçlanmıştır (Büyüköztürk, 2020). Terrblanche ve Boshoff'a (2006: s.38) göre doğrulayıcı faktör analizi (DFA); "önceden yapılmış olan uygulamalı araştırmalar ile tespit edilen ve teoriye dayalı olarak geliştirilen kavramsal yapıları ölçmede kullanılan ölçeklerin geçerlik ve güvenirlik düzeylerini belirlemeye yarayan istatistiksel bir analiz yöntemidir". Bu araştırma kapsamında Hu \& Bentler'in (1999) en çok kullanılan uyum indeks sonuçları kullanılmıştır. LISREL 8.51 istatistik programı ile ölçeğin belirli parametrelere uygunluğunu tespit etmek için Ki-Kare Uyum Testi (Chi-square Goodness of Fit Indices), Uyum İyiliği İndeksi (GFI), düzenlenmiş İyilik Uyum İndeksi (AGFI), Karşılaştırmalı Uyum İndeksi (CFI), Fazlalık Uyum İndeksi (IFI), yaklaşık hataların ortalama karekökü (RMSEA) gibi uyum indeksleri incelenmiştir (Hu \& Bentler, 1999).

Tablo 6. Ölçeğe ilişkin önerilen modelin doğrulayıcı faktör analizi uyum indeksler (Hu and Bentler,1999)

\begin{tabular}{lll}
\hline Ölçüm & Eşik Değerler & Mevcut Çalışma Modeli \\
\hline Chi-Square/df & $<3$ iyi; $<5$ izin verilebilir & 2.719 \\
(cmin/df) & & \\
p-value & $>.05$ & 0.000 \\
CFI & $>.90$ & 0.95 \\
GFI & $>0.9$ & 0.874 \\
AGFI & $>.80$ & 0.844 \\
IFI & $>.90$ & 0.917 \\
TLI & $>.90$ & 0.906 \\
RMSEA & $<.05$ İyi $;<.05-.10$ Orta & 0.069 \\
\hline
\end{tabular}

Doğrulayıcı faktör analizinde (DFA), modelin yeterliğini ortaya koymak üzere yapılan analiz sonucunda, ölçeğin dört boyutta uyumlu 
olduğu ve ki-kare değerinin $(\chi 2=609.150, \mathrm{df}=224, \mathrm{p}=0,00)$ anlamlı olduğu görülmüştür. İstatistikî olarak anlamlı Ki-kare $(\chi 2)$ değeri, önerilen modelin gözlenen veriye göre uygun olduğunu göstermektedir. Düzeltilmiş Ki-Kare ( $\chi 2)$ / (df) 1-5 aralığında önerilir ve ölçekte 2.719 çıkmıştır. Bu değer 5'ten küçük olduğundan ölçeğin iyi düzeyde uyum gösterdiği söylenebilir. Yaklaşık hataların ortalama karekökü (RMSEA) değeri .069 değeri ile 08'den küçük olması kabul edilebilir düzeydedir (Schoot vd., 2012). Uyum iyiliği indeksi (GFI) 874 değeri, düzeltilmiş uyum iyiliği indeksi (AGFI) .844, karşılaştırmalı uyum indeksi CFI değeri .916 değerlerinin, önerilen modelin 1'e yakın olması ölçek doğrulayıcı faktör analiz sonuçlarının kabul edilebilir düzeyde olduğunu ve faktör yapısının verilerle uyumlu olduğunu göstermektedir (Pallant ve Manual, 2007). Hu ve Bentler (1999) bir modelin iki ana koşuldan birini karşılaması halinde modelin kabul edilebileceğini ifade etmiştir. $\mathrm{Bu}$ değerler; ölçeğinin yapı geçerliğine ve oluşturulan modelin iyi bir uyuma sahip olduğunu göstermektedir. Tüm modele ilişkin uyum indekslerinin kabul edilebilir sınırlar içerisinde olduğu söylenebilir (Çokluk vd., 2018).

Şekil 1. incelendiğinde, DFA'den elde edilen ve faktörlerin maddelerle olan ilişkisini gösteren standardize edilmiş katsayıların 0.52 ile 0,87 arasında dağıldığı görülmektedir. Ölçeğin mevcut 23 maddenin, 4 ana faktöre ayrılmıştır. Ölçeğe ait path (yol) diyagramı incelendiğinde madde faktör yüklerinin .30 üzerinde çıkmıştır (Büyüköztürk, 2020). Maddelerin hata varyanslarının ise tüm maddeler içerisinde en yüksek 87 olmuştur. Sonuç olarak, AFA sonucu belirlenen faktör yapılarının DFA sonucu verileriyle yeterli düzeyde uyum gösterdiği söylenebilir. Ayrıca, ölçeği oluşturan maddelerin toplam ölçek puanı ile ilişki katsayıları incelendiğinde $\mathrm{r}=\quad .554$ ile $\quad .832$ arasında değiştiği görülmektedir. Bu bulgular, her bir maddenin toplam ölçek puanı ile yüksek düzeyde bir korelasyona sahip olduğu ifade edilebilir. Sonuç olarak, elde edilen uyum indeksleri ile modelin iyi bir yapıya sahip olduğu ortaya konulmuş ve ölçeklerin geçerliğine kanıt sunulmuştur. 


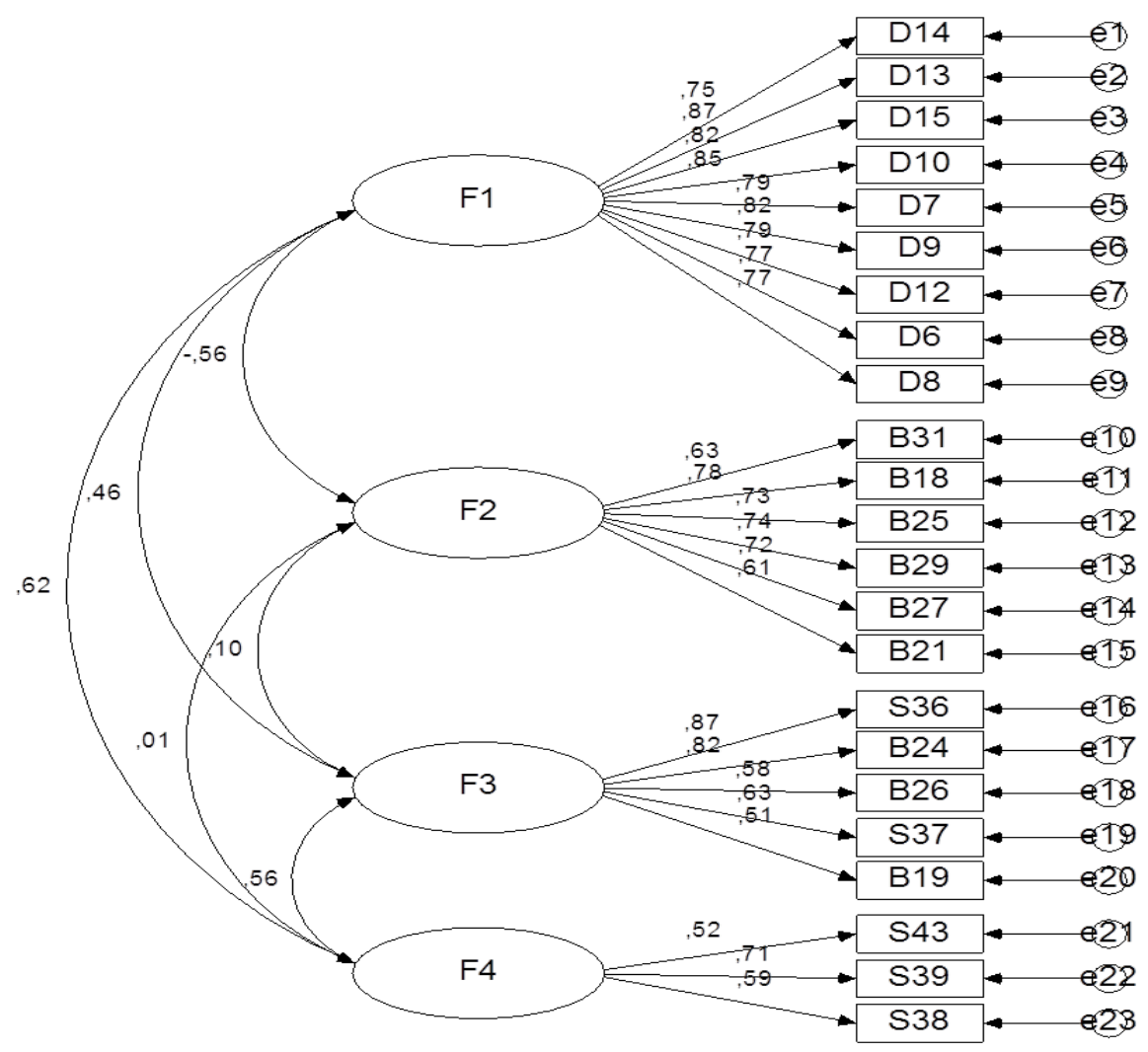

Şekil 1. Ölçeğe ait doğrulayıcı faktör analiz sonuçlarına ait diyagram

\section{Ölçeğe Son Hâlinin Verilmesi}

Ölçeğin geçerlik ve güvenirlik çalışmalarından elde dilen 23 madde ve 4 faktör, alanda uzman olan 3 kişinin görüş ve önerileri göz önüne alınarak adlandırılmıştır. Ölçeğin ismi alanyazındaki çalışmalar ve madde içeriklerine uygun olarak "Okul Temelli Denetim Yaklaşımları Ölçeği" olarak isimlendirilmiştir. İlk faktör "Gelişim Odaklı Denetim”, ikinci faktör "Otoriter Odaklı Denetim", üçüncü faktör "Isşlemsel Denetim", dördüncü faktör "Sosyal Ağdaşım Temelli Denetim" olarak adlandırılmıştır (Ek:1). Faktörler nihai olarak maddeler incelendiğinde ölçekte isim sıralama ve madde sayıları; 
Tablo 7. Ölçek boyutları ve madde sayıları

\begin{tabular}{llll}
\hline Sıra & Boyut & Madde Sayısı & Ölçek madde sırası \\
\hline 1. & Otoriter Odaklı Denetim & 6 & 1-6. maddeler \\
2. & Gelişim Odaklı Denetim & 9 & 7-15. maddeler \\
3. & İşlemsel Denetim & 5 & 16-20. maddeler \\
4. & Sosyal Ağdaşım Temelli Denetim & 3 & 21-23. maddeler \\
\hline
\end{tabular}

Tablo 7'de Glickman vd. (2014) “Denetim ve Öğretimsel Liderlik Gelişimsel Bir Yaklaşım" kitabında tanımladıkları üç farklı okul tipi temel alınarak oluşturulan ölçeğin karşılaştırmalı son hâli aşağıya çıkarılmıştır.

Tablo 8. Okul tipolojileri ve ölçekler

\begin{tabular}{lll}
\hline $\begin{array}{l}\text { Glickman, Gordon ve Gordon'un } \\
\text { tipolojileri }\end{array}$ & okul & Okul Temelli Denetim Yaklaşımları Ölçeği \\
\hline $1-$ & Geleneksel Okul & Otoriter Odaklı Denetim \\
$2-$ & Sosyal Etkileşimli Okul & Sosyal Ağdaşım Temelli Denetim \\
$3-$ & Meslektaş Odaklı Okul & Gelişim Odaklı Denetim \\
$4-$ & - & İşlemsel Denetim \\
\hline
\end{tabular}

Yukarda görüldüğü gibi Glickman vd. (2014) tanımladıkları üç farklı okul tipi kuramsal temelleri dikkate alınarak oluşturan "Okul Temelli Denetim Yaklaşımları Ölçeği" yapılan açımlayıcı ve doğrulayıcı faktör analizleri sonucu 4. faktör olarak "İşlemsel Denetim" ayrı bir boyut ortaya çıkmıştır.

Çalışmada oluşturulan ölçek, 23 madde ve 4 boyuttan oluşan "Okul Temelli Denetim Yaklaşımları" ölçekten elde edilecek minimum 23 ve maksimum 115 puan olup sonuçlar aşağıdaki tabloda belirtilen düzeye göre yorumlanmıştır;

Tablo 9. Ölçeğin katılım düzeyi ve puan aralıkları

\begin{tabular}{lll}
\hline Sıra & Katılım Düzeyi & Puan Aralı̆̆ $\mathbf{~}$ \\
\hline 1. & Kesinlikle Katılmıyorum & $1.00-1.80$ \\
2. & Katılmıyorum & $1.81-2.60$ \\
3. & Kismen katıllyorum & $2.61-3.40$ \\
4. & Katıliyorum & $3.41-4.20$ \\
5. & Kesinlikle Katıliyorum & $4.21-5.00$ \\
\hline
\end{tabular}


Okul Temelli Denetim Yaklaşımları Ölçeği 5 likert değerlendirmesi değer farkının (4) değer yargısına (5) bölünmesi ile oluşan $0.80^{\prime} l 1 k$ puan aralık düzeyi olarak kabul edilmiştir.

\section{Tartışma ve Sonuç}

$\mathrm{Bu}$ araştırmanın temel amac1, okul müdürlerinin okul temelli denetim yaklaşımlarını betimlemeye yönelik güvenilir ve geçerli bir ölçme aracı geliştirmektir. Çalışmada Türk eğitim sisteminde, okul temelli denetim yaklaşımlarını betimleyen, güvenilir ve geçerli bir veri toplama aracı geliştirerek uygulayıcılara ve alanyazına katkı sağlaması umulmaktadır.

Ölçek geliştirme sürecinde, DeVellis (2017) tarafından önerilen aşamalar temel alınmıştır. Bunun için öncelikle problem tanımlanmış ve geliştirilecek ölçeğin hangi özellikleri ölçeceğine karar verilmiştir. Geliştirilecek ölçek ilgili alın yazın taranması ile Glickman vd. (2014) “Denetim ve Öğretimsel Liderlik Gelişimsel Bir Yaklaşım” kitabında tanımladıkları üç farklı okul tipi olan "geleneksel okul, sosyal etkileşimli okul, meslektaş odaklı okul” tipleri temel alınarak madde havuzu oluşturulmuştur.

Madde havuzunun kapsam ve görünüş geçerliliği için alanında uzman olan eğitim bilimlerinde görevli 2 profesör, 3 doçent, 3 doktor öğretim üyesinden uzman yorumu için görüş ve önerileri alınmıştır. Ardından oluşan son hâli bir ölçme değerlendirme uzmanına ve son olarak ölçeğin dil açısından anlaşılırlığı ve imlâ kuralları için Türk dili ve edebiyatı alanı uzmanlarından görüş alınmıştır. Tüm uzman görüşlerinin değerlendirilmesi ve pilot uygulamasından sonra oluşan ölçek taslağın faktör analizleri yapılmıştır. Açımlayıcı Faktör Analizinde ölçeğin, öz değeri 1'den büyük olan dört faktör altında toplandığı tespit edilmiştir (Büyüköztürk, 2020). Dört faktöre ait maddelerin faktör yük değerleri .52 ile .87 arasında değişmektedir. Bu dört faktörün toplam varyans ve döndürülmüş bileşenler matrisi incelediğinde, 4 faktörün toplam varyans \% 64.089'nu olarak gerçekleşmiştir. Dört faktörde; birinci faktörün 25.660 oranında, ikinci faktörün 17.033 oranında, üçüncü faktörün 12.902 oranında ve dördüncü faktörün 8.494 oranında toplam varyansa katkı sağlamıştır. Ayrıca, sosyal bilimlerde varyans oranları \%40 ile \%60 arasında yeterli kabul edildiğinden (Şencan, 2005; Tavşancıl, 
2019) ulaşılan \%64.089 değerinin iyi bir oran olduğu söylenebilir. Ölçeğin ismi alanyazındaki çalışmalar ve madde içeriklerine uygun olarak "Okul Temelli Denetim Yaklaşımları Ölçeği" olarak isimlendirilmiştir. İlk faktör "Gelişim Odaklı Denetim", ikinci faktör "Otoriter Odaklı Denetim", üçüncü faktör "İşlemsel Denetim", dördüncü faktör "Sosyal Ağdaşım Temelli Denetim" olarak adlandırılmıştır.

Okul temelli denetim yaklaşımları ölçeğinin AFA ile belirlenen dört faktörlü yapısı Lisrel programı ile DFA yapılmıştır. Bu araştırma kapsamında $\mathrm{Hu}$ \& Bentler'in (1999) en çok kullanılan uyum indeks sonuçları referans olarak kullanılmıştır. DFA'da yapılan analiz sonucunda, ölçeğin dört boyutta uyumlu olduğu ve ki-kare değerinin $(\chi 2=609.150, \mathrm{df}=224, \mathrm{p}=0,00)$ anlamlı olduğu görülmüsstür. Düzeltilmiş Ki-Kare $(\chi 2)$ / (df) 1-5 aralığında önerilir ve ölçekte 2.719 çıkmıştır. Bu değer 5'ten küçük olduğundan ölçeğin iyi düzeyde uyum gösterdiği söylenebilir. Yaklaşık hataların ortalama karekökü (RMSEA) değeri ,069 değeri ile $08^{\prime}$ den küçük olması kabul edilebilir düzeydedir (Schoot vd., 2012). Uyum iyiliği indeksi (GFI) .874 değeri, düzeltilmiş uyum iyiliği indeksi (AGFI) .844, karşılaştırmalı uyum indeksi CFI değeri ,916 değerlerinin, önerilen modelin 1'e yakın olması ölçek doğrulayıcı faktör analiz sonuçlarının kabul edilebilir düzeyde olduğunu ve faktör yapısının verilerle uyumlu olduğunu göstermektedir (Gliner vd., 20015; Pallant ve Manual, 2007). Hu ve Bentler (1999) bir modelin iki ana koşuldan birini karşılaması halinde modelin kabul edilebileceğini ifade etmiştir. $\mathrm{Bu}$ değerlere göre; ölçeğinin yapı geçerliğine sahip ve oluşturulan modelin iyi bir uyuma sahip olduğunu göstermektedir. Tüm modele ilişkin uyum indekslerinin kabul edilebilir sınırları içerisinde çıkmıştır. Ölçeğin dört faktörlü yapısının kullanılabilir ve geçerli bir model olduğu sonucuna varılmıştır.

Okul temelli denetim yaklaşımları ölçeğinin güvenirliği Cronbach Alfa katsayısı ölçülmüştür. Ölçeğin bütün boyutların toplamında Cronbach's Alpha $(\alpha)$ değerinin .844 olması, ölçeğin yüksek güvenilir olduğunu göstermektedir (Büyüköztürk, 2020). Ölçeğin faktörler bazında Cronbach's Alpha $(\alpha)$ değerlerinin .63 ile .94 arasında çıkmıştır. $\mathrm{Bu}$ sonuca göre, ölçekteki maddeler için verilen cevapların tutarlı ve kullanılabilir olduğu söylenebilir. Hem ölçeğin tümü hem de faktörlerin aldığg Cronbach's Alpha $(\alpha)$ değerleri dikkate alındığında ölçeğin bir 
bütün olarak araştırma grubu için güvenilir olduğu sonucuna varılmıştır.

Okul temelli denetim yaklaşımları ölçeğinin geçerlik ve güvenirlik çalışmalarına ilişkin ulaşılan sonuçlar, ölçeğin okul müdürlerinin denetim yaklaşımlarını ölçmek için kullanılabileceğini göstermektedir. Çalışmada oluşturulan "Okul Temelli Denetim Yaklaşımları" ölçeği, 23 madde ve 4 boyuttan oluşmaktadır. Ölçek Likert tipi beşli derecelendirme ile kullanılmış (kesinlikle katılmıyorum=1, Katılıyorum=2, Kismen katılıyorum=3, katılıyorum=4 ve Kesinlikle katılıyorum=5) olup öğretmenler okul müdürlerinin ifade edilen davranışı katılma düzeyinin ne kadar gerçekleştirdiklerine dair işaretleyerek görüşlerini belirtmektedirler.

Sonuç olarak "Okul temelli denetim yaklaşımları ölçeği", dört boyutlu ve 23 madde olarak oldukça geçerli ve güvenilir bir ölçme aracı olduğu, geliştirilen ölçeğin okul müdürlerinin denetim yaklaşımlarına ilişkin geçerli ve güvenilir ölçüm yapabilecek bu konudaki yeterliklerini ve ilgili konudaki sorun alanlarını betimlemesi noktasında alana katkı sağlaması umulmaktadır. Ayrıca bu ölçek, doktora tez çalışmasındaki örneklem üzerinden elde edilen sonuçlara dayalı olarak (İş, 2021) alanda iyi bir veri toplama aracı olarak kullanılabileceği ve öğretimsel denetim sürecini daha bilimsel bir tabana oturmasına önemli katkılar sağlayacağ 1 ifade edilebilir. Geliştirilen ölçeğin, okul müdürlerinin denetim yaklaşımlarını belirlenmesinde kullanılması için önerilmektedir. 


\title{
EXTENDED ABSTRACT
}

\section{A Scale Development Study for the Assessment of School Principals' Supervisory Approaches}

\author{
Engin İş - M. Semih Summak \\ Gaziantep University
}

The main purpose of this study is to develop a valid and reliable scale that will determine the approaches of school principals in teacher supervision. Within the scope of this research, a scale development study was conducted on school-based auditing approaches. When scanning the literature in Turkey and abroad, the researcher has not encountered a scale for school-based auditing approaches of school principal. From this point of view, it is expected that this study, which aims to develop a scale for school principals' "school-based auditing approaches ", offers a useful contribution to the literature.

In the scale development process, the procedures suggested by DeVellis (2017) were performed. In this respect, first of all, the problem was defined and it was decided which features the scale to be developed would measure. The item pool of the scale was created as follows based on three different school types defined in Glickman et al. (2014) "Supervision and Instructional Leadership: A Developmental Approach":

1. Traditional school with features of hierarchy and professional loneliness.

2. Social interactive school with professional isolation and friendly interaction features.

3. Peer-oriented school types with a focus on improving learning and teaching.

Two professors, three associate professors and three assistant professors from the field of educational sciences were asked their opinions and suggestions on the conformity of created item pool in terms of content and construct valitiy. Then, the opinion of an expert from the assessment and evaluation field for the final version of the scale and the opinions of experts from the Turkish language and literature field for the 
comprehensibility of the scale were asked. Factor analysis of the draft scale, which was formed after the evaluation of all expert opinions and the pre-tiral application, were made. The load values of the items were examined by exploratory factor analysis. As a result of the factor analysis, it was determined that the scale was gathered under four factors with an Eigen value greater than 1 (Büyüköztürk, 2020). The items' loading values belonging to the four factors vary between .52 and .87. When the total variance of these four factors and the rotated components matrix were examined, it was found that the total variance of the 4 factors was $64.089 \%$. In four factors; 25,660 of the first factor, 17,033 of the second factor, 12,902 of the third factor and 8,494 of the fourth factor explains the total variance. In addition, considering that the variance values varying between $40 \%$ and $60 \%$ are sufficient in social sciences, it was concluded that the $64.089 \%$ value has a very good rate and the construct validity of the scale is at an acceptable level. Considering the contents of the items in the factors and the studies in the literature, the factors were given the following names: the first factor "Development Focused Supervision", the second factor "Authoritarian Focused Supervision", the third factor "Operational Control", the fourth factor "Social Network Based Supervision".

CFA was performed with the Lisrel program on the four-factored structure of the school-based auditing approaches' scale determined by EFA. Within the scope of this research, the most used conformity index results of $\mathrm{Hu} \&$ Bentler (1999) were used as a reference. As a result of CFA, it was seen that the scale was compatible in four dimensions and the chi-square value $(\chi 2=609.150, \mathrm{df}=224, \mathrm{p}=0.00)$ was significant. This value shows that the model has an acceptable goodness of fit. The corrected Chi-Square $(\chi 2) /(\mathrm{df})$ value is recommended in the range of 15. This value is 2.719 in the scale. As this value is less than 5, it can be said that the scale shows a good fit. Approximate root mean square error (RMSEA) value is acceptable level which is .069 and less than .08 (Schoot et al., 2012). shows that its structure is compatible with the data (Gliner et al., 20015; Pallant \& Manual, 2007). The goodness of fit index (GFI) .874 , adjusted goodness of fit index (AGFI) .844, comparative fit index (CFI) .916, and the proposed model being close to 1 show that the confirmatory factor analysis results of the scale are at an acceptable level 
and its structure is compatible with the data (Gliner et al., 20015; Pallant \& Manual, 2007). Hu and Bentler (1999) stated that a model can be accepted if it meets one of the two main conditions. According to these values, it shows that the scale has construct validity and that the created model has a good fit. These values show that the scale has construct validity and the created model has a good fit. It was found that fit indices for the entire model were in acceptable limits. As a result, it is possible to say that the four-factored structure of the scale is a usable and valid model.

The reliability of the the school-based auditing approaches scale was calculated by Cronbach's alpha coefficient. As Cronbach's Alpha $(\alpha)$ coefficient in the entire scale is .844, the scale is highly reliable (Büyüköztürk, 2020; Kalaycl, 2010). Cronbach's Alpha $(\alpha)$ coefficient values of the factors vary between .63 and .94 . Based on this result, it can be said that the answers given to the items in the scale are consistent and usable. Considering the Cronbach's Alpha $(\alpha)$ coefficient values of the entire scale and the factors, it was concluded that the scale was reliable for the research group. The results show that the scale is reliable on the basis of dimensions and as a whole. Validity and reliability results showed that school-based auditing approaches scale can be used to measure the school principals' auditing approaches. It is thought that this scale is convenient for measuring the constructivist learning environment management skills of elementary and high school teachers in Turkey.

As a result, "School-based auditing approaches scale" is thought to be a very valid and reliable measurement tool with 4 dimensions and 23 items. It is believed that this scale will contribute to the field in terms of describing the competencies and the problem areas in the related subject of school principals that can make valid and reliable measurement of auditing approaches. The developed scale is recommended to be used in determining the school principals' auditing approaches.

\section{Kaynakça / References}

Altun, B. (2014). Denetime eleştirel yaklaşım: Öğretmen denetimi nasıl olmalı. Yayımlanmamış Yüksek Lisans Tezi Adnan Menderes Üniversitesi, Sosyal Bilimler Enstitüsü, Aydın. 
Aslanargun, E. ve Göksoy, S. (2013). Öğretmen denetimini kim yapmalıdır? Uşak Üniversitesi Sosyal Bilimler Dergisi, Özel Sayı, 98-121.

Bülbül, T., Özdem, G., Tunç, B., ve İnandı, Y. (2013). Okul temelli değerlendirme algısı: Öğretmen görüşlerine dayalı betimsel bir analiz çalışması. Kuram ve Uygulamada Eğitim Bilimleri, 13(4), 21052124.

Büyüköztürk Ş. (2020). Sosyal bilimler için veri analizi el kitabı. Ankara: PegemA yayınları

Can, A. (2018). SPSS ile bilimsel araştırma sürecinde nicel veri analizi. Pegem Atıf İndeksi, 001-429.

Can, E., ve Gündüz, Y. (2016). İlkokullarda çalışan öğretmenlerin, maarif müfettişleri ve okul müdürlerinin yapmış olduğu rehberlik çalışmalarından yararlanma düzeylerinin incelenmesi. Kuram ve Uygulamada Egitim Yönetimi Dergisi, 22(1), 1-28.

Catano, N., ve Stronge, J. (2007). What do we expect of school principals? Congruence between principal evaluation and performance standards. International Journal of Leadership in Education, 10(4), 379399.

Creswell, J. W. (2009). Research design: Qualitative and mixed methods approaches. London and Thousand Oaks: Sage Publications.

Çokluk, Ö., Şekercioğlu, G., ve Büyüköztürk, Ş. (2018). Sosyal bilimler için çok değiş̧kenli istatistik: SPSS ve LISREL uygulamaları. Anakara: Pegem Akademi.

David, J.L., (1996), The who, what, and why of site-based management, Educational Leadership,53(4), 4-9.

Davies, D., and Rudd, P. (2001). Evaluating school self-evaluation. Slough: NFER.

Deniz, Ü., ve Saylık, N. (2018). Okul müdürleri ve öğretmenlerin Perspektifinde öğretimde denetim problemiI. Uluslararası Liderlik Çalışmaları Dergisi: Kuram ve Uygulama, 1(1), 67-80.

DeVellis, R.F. (2017). Ölçek Geliştirme. Ankara: PegemA yayınları.

Dufor, R. ve Berkey, T. (1995). The principal as staff developer. Journal of staff Development. 16(4), 2-2.

Edmonds.R. (1979). Effective Schools for Urban Poor, Educational Leadership, $37,14-21$ 
Fırıncıoğulları, E. (2014). İlkokul müdürlerinin ders denetimleri ile ilgili öğretmen görüşleri (Yayımlanmış Yüksek Lisans Tezi). Adnan Menderes Üniversitesi Sosyal Bilimler Enstitüsü, Aydın, Türkiye.

Glanz, J. (2006). What Every principal should know about instructional leadership. California: Corwin Pres. Inc.

Glickman, C. D. (1985). Supervision of instruction: A developmental approach. Publication Sales, Allyn and Bacon.

Glickman, C. D. (2002). Leadership for learning: How to help teachers succeed, association for supervision and curriculum development Alexandria. Virginia, USA

Glickman, C. D., Gordon, S. P., ve Ross-Gordon, J. M. (2014). Denetim ve öğretimsel liderlik: Gelişimsel Bir Yaklaşım. (M.B. Aksu E. ve Ağaoğlu, Çev). Ankara: Anı Yayıncılık.

Gliner, J. A., Morgan, G. A., and Leech, N. L. (2015). Uygulamada araştırma yöntemleri: Desen ve analizi bütünleştiren yaklaşım (Çev. Ed.: Selahattin Turan). Ankara: Nobel yayın dağıtım.

Grimm, L. G. and Yarnold, P. R. (1995). Reading and understanding multivariate statistics. Washington, DC: American Psychological Association.

Grizzard, T. (2007). The impact of instructional leadership on school climate: a model for principal and teacher improvement (Unpublished Phd Thesis). Tennessee State University, Nashville.

Gümüşeli, A.İ. (2014). Eğitim ve öğretim yönetimi. Ankara, Pegam A Yayınları Gündüz, Y. (2016). Öğretmenlerin denetimlere ilişkin görüşleri: Müfettişler mi? Okul müdürleri mi?. Pegem Atı İndeksi, 809-822.

Harris, B. M. (1985). Supervisory behavior in education. New Jersey: PrenticeHall, Inc.

Heck, R., Larsen, T. ve Marcoulides .G. (1990). İnstructional Leadership and School achievement: Validation of a Causal Model. Educational Administration Quarterly, 26(2), 94-125

Hofman, R. H., Dijkstra, N. J., and Hofman, W. H. A. (2009). School selfevaluation and student achievement. School Effectiveness and School Improvement, 20(1), 47-68.

$\mathrm{Hu}$, L., and Bentler, P. M. (1999). Structural equation modeling: Cutoff criteria for fit indexes in covariance structure analysis: Conventional criteria versus new alternatives. Structural Equation Modeling: A Multidisciplinary Journal, 6(1), 1-55. 
Kalaycl, Ş. (2010). SPSS uygulamalı çok değişkenli istatistik teknikleri (Vol. 5). Ankara, Turkey: Asil Yayın Dağıtım.

Kline, R. B. (2005). Principles and practice of structural equation modeling (2PndP Ed.). New York: Guilford.

Luehe, B. (1989). The Principal and Supervision. Elementary Principal Series No. 4. Publication Sales, Phi Delta Kappa Educational Foundation, 8th and Union, Bloomington, IN 47402.

Melenyzer, B. J. (1990). Teacher Empowerment: The discourse, meanings and social actions of teachers. The Annual Conference of the national Counsil of states on Insirvice Education, Orlando, Florida.

Memduhoğlu, H. B. ve Zengin, M. (2012). Çağdaş eğitim denetimi modeli olarak öğretimsel denetimin Türk eğitim sisteminde uygulanabilirliği. Kuramsal Ĕ̆itimbilim Dergisi, 5(1), 131-142.

Mohanty, J. (2005). Educational administration, supervision and school management. USA: Deep and Deep Publications.

Oliva, P. F., and Pawlas, G. E. (2004). Supervision for today's schools. JosseyBass, An Imprint of Wiley. 10475 Crosspoint Blvd, Indianapolis, IN 46256.

Pallant, J., and Manual, S. S. (2007). A step-by-step guide to data analysis using SPSS for windows. SPSS Survival Manual. Open University Press, New York.

Sergiovanni, T. J. ve Starratt, R. J. (1979). Supervision human perspectives.USA: McGraw-Hill, Inc.

Schoot, R.V., Lugtig, P. ve Hox, J. (2012) Ölçüm değişmezliğini test etmek için bir kontrol listesi. Avrupa Gelişim Psikolojisi Dergisi, 9(4), 486492, DOI: $10.1080 / 17405629.2012 .686740$

Sullivan, S., and Glanz, J. (2015). Okullarda ĕgitim ve öğretimi geliştiren denetim. (Ali Ü, çev.). Ankara: Anı Yayıncılık.

Summak, M.S. ve İş, E. (2018). Okul müdürlerinin öğretimsel denetim yeterliklerine ilişkin, içsel (Intrinsic) bir örnek olay çalışması. Eğitim Yönetimi Araştırmaları, e-kitap e-ISBN: 978-605-4561-66-7, 25-45

Sweney, (1992). Reserch synthesis on effective school leadership. Educational Leadeship. 39(5), 346-352

Şencan, H. (2005). Sosyal ve davranışsal ölçümlerde güvenirlik ve geçerlilik. Ankara: Seçkin Yayıncılık.

Tabachnick, B.G. and Fidell, L.S. (2007). Using multivariate statistics (5th ed.). Pearson Education, Inc. / Allyn and Bacon. 
Tavşancıl, E. (2019). Tutumların ölçülmesi ve SPSS ile veri analizi. Anakara: Nobel Akademik Yayıncilik

Terblanche, N. S., and Boshoff, C. (2006). The relationship between a satisfactory in-store shopping experience and retailer loyalty. South African Journal of Business Management, 37(2), 33-43.

Terry, P. M. (1999). Empowering teachers as leaders. In National Forum of Teache Education Journal ,10(3), 1-7.

Tonbul, Y. ve Baysülen, E. (2017). Ders denetimi ile ilgili yönetmelik değişikliğin maarif müfettişlerinin, okul yöneticilerinin ve öğretmenlerin görüşleri açısından değerlendirilmesi. Illköğretim Online, 16(1), 299-311.

Thrupp, M. (1998). Exploring the politics of blame: school inspection and its contestation in New Zealand and England. Comparative Education, 34(2), 195-209.

Yeşil, D. ve Kış, A. (2015). Okul müdürlerinin ders denetimine ilişkin öğretmen görüşlerinin incelenmesi. İnönü Üniversitesi Ĕ̆itim Bilimleri Enstitüsü Dergisi, 2(3), 27-45.

Yıldız, B., Akbaşlı, S., ve Üredi, L. (2016). Maarif müfettişlerinin sınıflarda uyguladığ1 rehberlik ve denetim uygulamalarının kaldırılmasına ilişkin öğretmen görüşleri. Turkish Studies, 11(3), 2427-2454.

Zepeda, S.J. (2007). The principal as instructional leader. A handbook for supervisors. (2nd edition). Larchmont, NY: Eye on Education.

Zepeda, S. J. (2016). Öğretim denetimi: uygulama araçları ve kavramlar. Ankara: Pegem A Yayıncilık. 
Ek:1

\section{OKUL TEMELLİ DENETIM YAKLAŞIMLARI ÖLÇEĞİ}

\section{DENETIM UYGULAMALARI BÖLÜMÜ}

2- Okul Müdürünüz Tarafından Denetim Geçirdiniz mi?

- Evet, sınıfımda müdür ders denetimi YAPTI : ( ) Yaptı ise kaç kez...

- Hayır, sınıfımda müdür ders denetimi YAPMADI: ( )

Cevabınız evet ise Lütfen Aşağıdaki Ölçeği Doldurunuz.

\begin{tabular}{|c|c|c|c|c|c|c|}
\hline 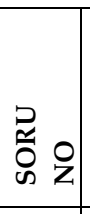 & $\begin{array}{l}\text { OKUL TEMELLİ } \\
\text { ÖLÇEĞİ }\end{array}$ & 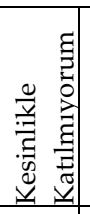 & 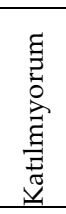 & 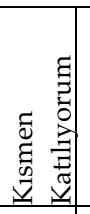 & 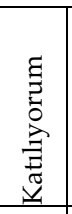 & 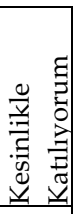 \\
\hline 1 & $\begin{array}{l}\text { Müdür, denetimi sonuç odaklı (not vermek için) } \\
\text { yapar. }\end{array}$ & ( ) & ( ) & ( ) & ( ) & ( ) \\
\hline 2 & Müdür, denetimi rapor ve dosya üzerinde yapar. & () & () & () & () & $($ ) \\
\hline 3 & Müdür, denetim sürecinde tek söz sahibidir. & () & $($ ) & () & $($ ) & () \\
\hline 4 & $\begin{array}{l}\text { Müdür, denetim sürecinde öğretmenlerle } \\
\text { ilişkilerinde katı ve resmidir. }\end{array}$ & ( ) & ( ) & ( ) & ( ) & $($ ) \\
\hline 5 & $\begin{array}{l}\text { Müdür, denetim sürecinde öğretmenlerin } \\
\text { hataları üzerine yoğunlaşır. }\end{array}$ & ( ) & ( ) & ( ) & ( ) & ( ) \\
\hline 6 & $\begin{array}{l}\text { Müdür, denetim sürecinde öğretmeni } \\
\text { değerlendirmede nesnel (tarafsız) olma kaygısı } \\
\text { taşımaz. }\end{array}$ & ( ) & ( ) & ( ) & ( ) & ( ) \\
\hline 7 & $\begin{array}{l}\text { Müdür denetim sürecinde tarafsız, adil ve şeffaf } \\
\text { davranır. }\end{array}$ & ( ) & ( ) & ( ) & ( ) & ( ) \\
\hline 8 & $\begin{array}{l}\text { Müdür, yaptı̆̆ı denetim ile öğretmenin öz } \\
\text { değerlendirme (kendi öğretim uygulamalarını) } \\
\text { becerilerini geliştirir. }\end{array}$ & ( ) & ( ) & () & ( ) & $($ ( ) \\
\hline 9 & $\begin{array}{l}\text { Müdür, yaptı̆̆ denetimde öğretmenin bağımsız } \\
\text { kararlar vermesini cesaretlendirir. }\end{array}$ & ( ) & ( ) & ( ) & ( ) & ( ) \\
\hline 10 & $\begin{array}{l}\text { Müdür, denetim sürecinde öğretmen ile işbirliği } \\
\text { yapar. }\end{array}$ & () & $($ ) & () & ( ) & ( ) \\
\hline 11 & $\begin{array}{l}\text { Müdür, denetim sürecinde öğretmenlerin } \\
\text { motivasyonunu artırıcı çalışmalar yapar. }\end{array}$ & ( ) & $($ ) & ( ) & ( ) & ( ) \\
\hline 12 & $\begin{array}{l}\text { Müdür, denetim sürecinde eğitim öğretimin } \\
\text { kalitesini artırmayı amaçlar. }\end{array}$ & ( ) & ( ) & ( ) & ( ) & ( ) \\
\hline 13 & $\begin{array}{l}\text { Müdür, denetim sürecinde öğretmenin kendisini } \\
\text { değerli hissetmesini sağlar. }\end{array}$ & ( ) & ( ) & ( ) & ( ) & ( ) \\
\hline 14 & $\begin{array}{l}\text { Müdür, denetim sürecinde öğretmene mesleki } \\
\text { liderlik yapar. }\end{array}$ & () & $($ ) & () & () & ( ) \\
\hline
\end{tabular}




\begin{tabular}{|c|c|c|c|c|c|c|}
\hline 15 & $\begin{array}{l}\text { Müdür, denetim sürecinde öğretmenle } \\
\text { meslektaş (işbirlikçi öğrenme) ilişkisi içindedir. }\end{array}$ & ( ) & ( ) & ( ) & ( ) & ( ) \\
\hline 16 & $\begin{array}{l}\text { Müdür, denetim sürecinde resmi kurallara ne } \\
\text { kadar uyulduğunu kontrol eder. }\end{array}$ & ( ) & ( ) & ( ) & ( ) & ( ) \\
\hline 17 & $\begin{array}{l}\text { Müdür, denetim sürecinde öğretmenin disipline } \\
\text { riayeti ve amirlerine karşı tutum ve } \\
\text { davranışlarına önem verir. }\end{array}$ & ( ) & ( ) & ( ) & ( ) & ( ) \\
\hline 18 & $\begin{array}{l}\text { Müdür, denetim sürecinde öğretmenin yaptığ } \\
\text { işlerin ilgili mevzuata uygun olmasına özellikle } \\
\text { dikkat eder. }\end{array}$ & ( ) & ( ) & ( ) & ( ) & ( ) \\
\hline 19 & $\begin{array}{l}\text { Müdür, denetim sürecinde öğretmenin okulun } \\
\text { genel işleyişine katkıda bulunup bulunmadığına } \\
\text { dikkat eder. }\end{array}$ & ( ) & ( ) & ( ) & ( ) & ( ) \\
\hline 20 & $\begin{array}{l}\text { Müdür, denetim sürecinde öğretmenin personel } \\
\text { ve idare ile uyumunu dikkate alır. }\end{array}$ & ( ) & ( ) & ( ) & ( ) & ( ) \\
\hline 21 & $\begin{array}{l}\text { Müdür, denetim sürecinde kişiler arası iletişimi } \\
\text { tehlikeye atacak uygulamalardan kaçınır. }\end{array}$ & ( ) & ( ) & ( ) & ( ) & ( ) \\
\hline 22 & $\begin{array}{l}\text { Müdür, denetim sürecinde öğretmenin yararı } \\
\text { için kendi önceliklerinden vazgeçer. }\end{array}$ & ( ) & ( ) & ( ) & ( ) & ( ) \\
\hline 23 & $\begin{array}{l}\text { Müdür, denetim sürecinde öğretimsel } \\
\text { amaçlardan çok öğretmenlerin beklentilerini göz } \\
\text { önünde bulundurur. }\end{array}$ & ( ) & ( ) & ( ) & ( ) & ( ) \\
\hline
\end{tabular}

\section{Kaynakça Bilgisi / Citation Information}

İş, E. ve Summak, M. S. (2021). Okul Müdürlerinin, Okul Temelli Denetim Yaklaşımlarını Belirlemeye Yönelik Bir Ölçek Geliştirme Çalışması. OPUS-Uluslararası Toplum Araştırmaları Dergisi, 18(40), 2500-2529. DOI: $10.26466 /$ opus.862427. 